International Journal of Current Advanced Research

ISSN: O: 2319-6475, ISSN: P: 2319 - 6505, Impact Factor: SJIF: 5.995

Available Online at www.journalijcar.org

Volume 6; Issue 3; March 2017; Page No. 2831-2835

DOI: http://dx.doi.org/10.24327/ijcar.2017.2835.0119

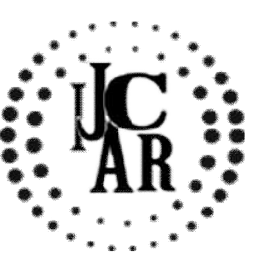

Research Article

\title{
EDUCATION AND LIVELIHOOD: A SOCIOLOGICAL STUDY ON GALO TRIBE IN BASAR CIRCLE OF ARUNACHAL PRADESH
}

\author{
Nabarun Purkyastha and Karken Bam
}

Department of Sociology University of Science \& Technology, Meghalaya (USTM) Khanapara, Techno City: Kling Road, Baridua: 9th Mile, Meghalaya: 793101

\section{A R T I C L E I N F O}

\section{Article History:}

Received $20^{\text {th }}$ December, 2016

Received in revised form $24^{\text {th }}$ January, 2017

Accepted $4^{\text {th }}$ February, 2017

Published online $28^{\text {th }}$ March, 2017

\begin{abstract}
A B S T R A C T
Education is an essential component for overall development of any society. It is the key factor in the development of human potentials. It not only gives knowledge but also act as an agent to make an individual capable to participate in social, economic and political activities. The study is an attempt to highlight the educational status and living condition on Galo Tribe in Basar Circle of Arunachal Pradesh.
\end{abstract}

\section{Key words:}

Arunachal Pradesh, Basar Circle, Galo Tribe, Socio-Cultural life, Educational Institution.

Copyright $₫ 2017$ Nabarun Purkyastha and Karken Bam. This is an open access article distributed under the Creative Commons Attribution License, which permits unrestricted use, distribution, and reproduction in any medium, provided the original work is properly cited.

\section{INTRODUCTION}

The importance of education cannot be stated enough. It is a self-enlightening process. Education is crucial to the overall development of an individual as well as the society at large. E. George Payne, the father of educational sociology, defines educational sociology as: "By educational sociology we mean... the social relationship in which the individual gains and organises his experience. This social relationship is regarded particularly in relation to the educational system in its evolution and changing functions." The study of educational status of an area is basically needed in order to check whether the status of the people has risen or remained stagnant.The educational attainment of a society's population is an important indicator of the society's stock of human capital and its level of socio-economic development. In order to acquire a better quality of life and to generate development, education is of great importance among the other factors. It is also mean to develop the personality of individuals, make them capable to perform certain economic activities, take part in political sphere and thereby improves their socio-economic status. When an individual has greater knowledge of personal and social skill, the person becomes more efficient to access and use information to maintain and improve their own and their family member's health. In this manner, in a society,

\footnotetext{
*Corresponding author: Nabarun Purkyastha

Department of Sociology University of Science \& Technology, Meghalaya (USTM) Khanapara, Techno City:

Kling Road, Baridua: 9th Mile, Meghalaya: 793101
}

\section{METHODOLOGY}

The data has been collected in both primary and secondary sources. Secondary data was collected from the census and other sources like books, journals etc. and after that for the collection of primary data, an "Interview scheduled" was used to interview the respondent and the method for selecting my sample was "Purposive Sampling Method" and also through field observation and narrative analysis for the study.

\section{REVIEW OF LITERATURE}

HemlataTalesra (1989) studied on the structure and role of education in accelerating the process of tribal integration. He argues that some alternative model of education should be developed which could help the tribes to seek their incorporation in the regional and mainline civilization and solve the problems on the idiom of distributive justice.

NikunjaBihariBiswas (2008) examines the development of education, school education, higher education, teacher education, adult education, vocational education and technical education, women education, educational management, panchayati raj and educational planning in North Eastern region of India. It not only provides brief discussion about the modern period of education but also of the ancient times.

TamoMibang and N.C. Behera (2004) studies the various programs and projects, launched by the central and state government for the development of S.T.s, and how far it became effective in ameliorating the lot of tribal of Arunachal Pradesh. They believes that a new class of elite tribal group has emerged, which gained from the benefits of the tribal 
development programmes specially in the field of education and on the other side of the coin there are tribal's still languishing in poverty.

A.S. Seetharamu (1980) studies the rural response to 21 developmental programme of the state. Its study covers the department of agriculture, horticulture, animal husbandry and veterinary services, industry and commerce, health and family welfare, power, irrigation and social welfare etc. Data have been collected from 1834 respondents from 86 villages in 2 Taluks which differ in their educational background. He basically highlighted the need and importance of vitalizing extension services in rural areas.

P.T. Nair (1985) studied about the tribesmen of the state Arunachal Pradesh. This study has given an overall view of their life with special reference to their youth dormitories, marriage customs, slavery and primitive weapons and warfare, which are fast disappearing.

A.G. Fresher (1986)as a chairperson of the British commissioncomprises a report of a commission appointed by missionary societies in Great Britain, to enquire about the educational status of the Indian villages. Although the report is old the contents of the report are still useful to the planners and policy makers in the field of education in India.

Narendra K. Singhi (1979) discussed about status of S.C.s and S.T.s and to evaluate the extent to which education as well as other forces of modernization have been effective in eradicating sources of inequality and in generating equalitarian and non-discriminatory pattern of relationship.

L.R.N Srivastava (1962) basically focuses on the Galo tribe of West-Siang district of Arunachal Pradesh. His study reflects a brief account of these charming people, their beautiful countryside, their domestic and social and educational life, political organization and religion.

J.C. Aggarwal (2008) discussed about the philosophical and sociological perspectives of education in the context of Indian Society. The material in this book has been drawn from the reports of Committees and Commissions, Resolutions and national policies on education.

SunitaAgarwalla (2008) has put effort to include every topic on education as per the requirement of the syllabus of Gauhati University. This book has given special attention to the language where simpler terms have been used to be easily understood by the beginners.

Christoph Von FurerHaimendorf (1971) study of Apa Tanis of Arunachal Pradesh highlights about its division into upperclass and commoner. Village authority is vested in a number of persons of the upper class who have some status. Hisstudy also reflects the educational status of Apatani tribe in Arunachal Pradesh.

S.T Das (1987) studied people of India including a large number of primitive tribes, who subsist hunting, fishing or by single form of agriculture. He says racial origin of Indian scheduled tribes has been traced as Proto-Austroloids, who one time practically covered whole of India. Secondly, Mongoliods who are still located in Assam and North-East India and finally to a limited extent the Negritos having frizzy hair, they are Andamaneese and the Kadars of the South-west India.

M.K Raha and P.C Commer (1989) say tribes in India usually encounter problems in their day-to-day life. Policy adopted by government, both at centre and states to promote their socioeconomic conditions and educational standards have some positive influence among of scheduled tribes.

Devendra Thakur and D.N Thakur (1996) view tribal people as original inhabitants of India, constitute a significant part of vast nation. They have been dwelling in forests surrounding by hills for a long period. Their social structure, culture and language are quite different from general people. In post independent age, a lot of changes have taken place in tribal areas due to large Endeavour of government for their socioeconomic and educational development. In spite of all endeavors, they are still poor as well as illiterate and are far from the mainstream of Indian society.

M. Horan (1978) in his study highlights processes of social change in Nagaland. He offers an insider's view about passing of traditional tribal structure into a relatively modern and developed state. He has thrown light on impact of British administration, Christian missionaries and political unrest generated by the underground movement on Naga society and polity. He draws attention to affectivity and vitality of some tribal institutions in Nagaland.

K.K Misra (1994) in his study of Khamti tribe of Arunachal Pradesh views that elite's play role of effective catalysts in bringing social transformation in that society. Khamti tribe has undergone a state of transition, caught between the forces of tradition and modernity. His study highlights basic aspects of continuity and simultaneous emergence of new elites as a result of modern democratic process.

\section{The Land and the People}

Basar is a census town in the West Siang district of Arunachal Pradesh, India. It has an average elevation of 578 meters above mean see level and has a pleasantly cold weather. There are many villages under Basar Circle such as, Bam, Chirne, Disi, Ego-Yamin, Gori, Kamdak, Kadi, Nyigam, Nyodu, Pagi, Pajo, Piri, Regi, Sago, Sibe, Siru and Soi.

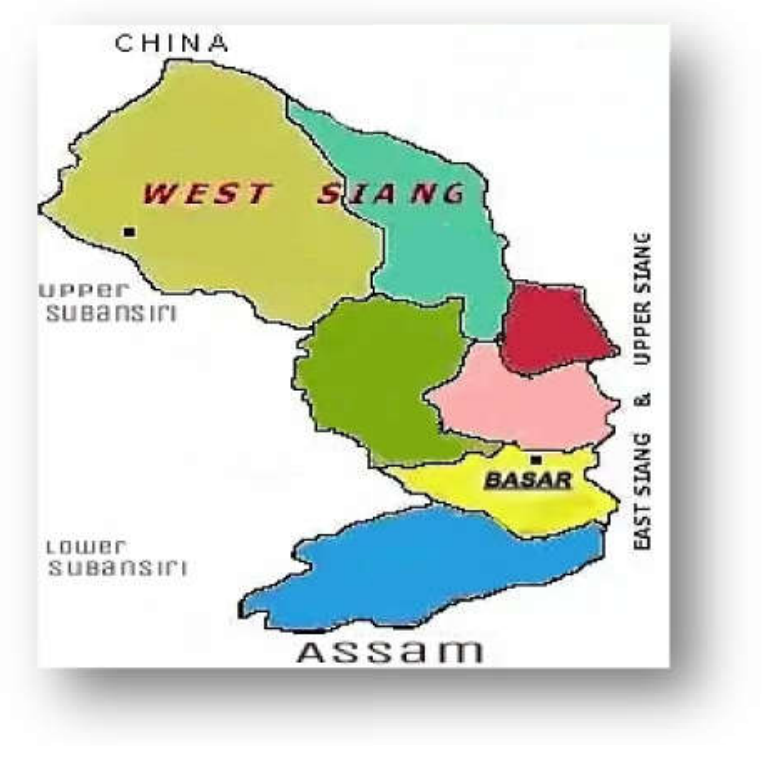




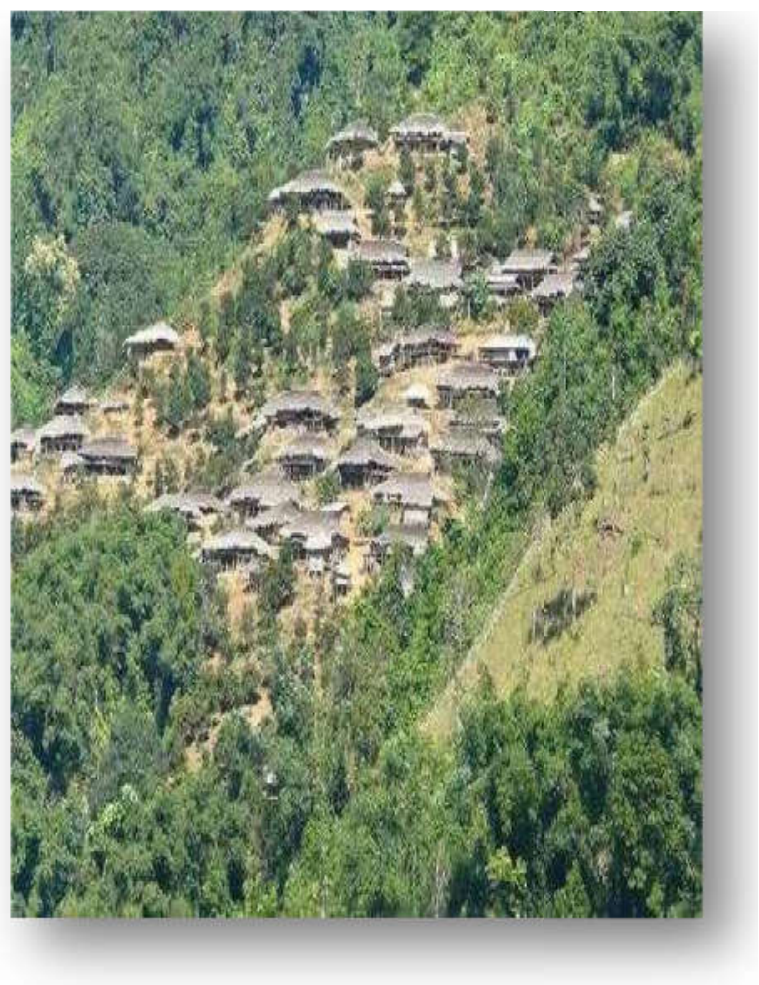

Galo Village: As per 2001 India census, total population of Basar circle is 3834 Galo tribe people, Males make up 56\% of the population and females form $44 \%$. The staple crop of the Galo people of Basar is rice, maize in slash-and-burn agricultural practice. The plain of the Basar valley is famous for its wet rice cultivation. Orange and pineapple are grown abundantly and nowadays even kiwis are tried in higher ridges of the mountain ranges.

The Galo Tribe: The tribe of Basar speaks Galo (Lare) language, which basically is related to Chinese or mongoloid languages. The dress of the Galo people, which is worn by both the sexes, is self-woven Beke tied around the body below the naval region to toes completely covering the lower portion in women. Men wear a self-woven sleeveless shirt called tango which is covered by a raw silk cloth wrapped over the shoulder. The lower portionis covered by a loin cloth called Haabewhich is passed between the buttocks. The head is covered by a cap-like called as Boluphand crafted from cane, which acted as a helmet during older wary days. In terms of religion majority people in Basar follow Donyi-poloism which involves the chanting of rhymes to appease the ancestors, many gods and goddesses by sacrificing animals .The priest called as Nyiboplays a crucial role here as an intermediary between the god (sun and moon) and the people.The mother of festivalmopinan agricultural festival performed before or after the sowing of seeds for bumper crops is celebrated in Basar usually in the month of April. Applying of itti on their faces, Popirsongs and dances of Mopin are performed during this festival.

\section{Educational Institutions in Basar Circle}

In the past due to the absence of formal educational system, most of the tribes in India had their own traditional institutions which provided education in the realm of social norms and customs, traditions and cultures, behavioral pattern and the laws of the society, taboos and ethics and religion of society. Educations among tribes were usually imparted through the family, which is being the smallest and primary unit of social organization. However the coming of modern education completely changed the tribal educational system. Various programmes and projects have been launched by central and state government in India since independence for the development of S.T.s. Arunachal Pradesh, earlier known as North Eastern Frontier Agency (N.E.F.A), is one of the 8 sisters of north east India which is still in the developing stage. The current educational system in Arunachal Pradesh is relatively underdeveloped. The state government is expanding the educational system in concert with various NGOs like Ramakrishna Mission (R.K.M.) and Vivekananda Kendra vidyalaya (V.K.V.). Arunachal University or Rajiv Gandhi University (R.G.U.), established in 1984, is the premier institution of higher learning of the state of Arunachal Pradesh. Whereas North Eastern Regional Institute Of Science and Technology (N.E.R.I.S.T) is playing an important role in raising the technical and management education.

There are many tribes in Arunachal Pradesh, like Nyishi, Apatani, Adi, Galo, Tagin, Monpa, Khamti, Nocte and so on who ought to have received proper attention considering the fact that they are the inhabitants of the largest state in the Northeast India. The Galos, one of the most joyful tribe of Arunachal Pradesh, are distributed in the region bordered by the middle and lower reaches of the Siyom River in the north, the Himalayan foothills in the south, the Siang River in the east and the Subansiri River in the west. Their main concentration is near Basar and Aalo. Galo people live in sparsely populated villages. Often a single clan occupies the whole of a village. The Galos have a favorable attitude towards education and majority of the boys and girls study up to the graduate and post graduate levels.In Basar itself there are various government/private/NGOs running institutions which cater to their needs. They are basically fully alive to the benefits of administration and their unstinted co-operation has made it possible to start Co-operative societies in their habitat. The key academic resource in Basar is the Tomi Polytechnic College under Rajiv Gandhi University (R.G.U.), Doimukh which is approved by AICTE, DHTE Government of Arunachal Pradesh. A government model degree college for Humanities has started functioning from session 2015-16. Basar has a mean literacy of $72 \%$ higher than the country wide mean of $59 \% .61 \%$ of the males and $39 \%$ of the females are literate.

Vivekananda KandraVidalayaBasar: Started in July 2008.It is a non-residential co-educational primary school located at Basar, $50 \mathrm{Kms}$ away from Aalo, and the Head Quarter of West Siang District. There were 87 students ( 56 boys and 31 girls), studying in classes $\mathrm{I}$ to $\mathrm{V}$ during its first year of academic session. The school is supported by local populace, Govt. administration and paramilitary units deployed in that area. It is basically a NGO running institution which has shown its excellency in its academic progress in all over the state from the last decade.

Tomi Polytechnic: Tomi Polytechnic College was established in the year 2006 and affiliated to Directorate of Higher and Technical Education, Govt. of Arunachal Pradesh.Besides these as per recent record, in Basar circle there are nine govt. primary schools in different villages like Sibe, Siru, Galu, Kamdak, Regi, Soi, Disi, Piri, and Esi-Chiku and eight govt. middle schools are also found in Nyodu, Basar Town, Nyigam, Gori, Pagi, and Sago. There is one govt. secondary 
school in Bam village and one higher secondary school in Basar town. As far as private institution is concerned there are middle schools, two numbers of secondary school and one higher secondary school in Basar town.

\section{Profile of the Respondents}

Profile of the respondents is determined by age group, religion, and marital status, types of family, source of income and educational life of theGalo tribe in Basar Circle of West Siang district of Arunachal Pradesh.
Source of family income: Above data reveal that $62 \%$ of the respondents are engaged in government service. It implies that majority of the people rely on government jobs for their livelihood. It is also found that $16 \%$ out of the total respondents are still engaged in agriculture. Although modernization has changed the occupational structure of the people, there are still people who practice traditional occupation i.e. agriculture.

Table no 1 Profile of the Respondent

\begin{tabular}{|c|c|c|c|c|}
\hline Sl.no & \multicolumn{2}{|c|}{ Profile } & Frequency & Percentage (\%) \\
\hline \multirow{6}{*}{1.} & \multirow{6}{*}{$\begin{array}{l}\text { Age Group of the } \\
\text { Respondent }\end{array}$} & 20-30 Years & 11 & $22 \%$ \\
\hline & & $31-40$ Years & 03 & $06 \%$ \\
\hline & & 41-50 Years & 12 & $24 \%$ \\
\hline & & 51-60 Years & 15 & $30 \%$ \\
\hline & & $61-70$ Years & 08 & $16 \%$ \\
\hline & & $71-80$ Years & 01 & $02 \%$ \\
\hline \multirow{2}{*}{2.} & \multirow{2}{*}{ Religion } & Donyipoloism & 32 & $64 \%$ \\
\hline & & Christian & 18 & $36 \%$ \\
\hline \multirow{2}{*}{3.} & \multirow{2}{*}{ Types of Family } & Joint family & 14 & $28 \%$ \\
\hline & & Nuclear family & 36 & $72 \%$ \\
\hline \multirow{6}{*}{4.} & \multirow{6}{*}{$\begin{array}{c}\text { Monthly Family Income } \\
\text { of Respondents }\end{array}$} & Below Rs. 10,000 & 03 & $06 \%$ \\
\hline & & Rs. 10,000 - Rs. 20,000 & 15 & $30 \%$ \\
\hline & & Rs. $20,000-$ Rs. 30,000 & 10 & $20 \%$ \\
\hline & & Rs. $30,000-$ Rs. 40,000 & 06 & $12 \%$ \\
\hline & & Rs. $40,000-$ Rs. 50,000 & 04 & $08 \%$ \\
\hline & & Above Rs. 50,000 & 12 & $24 \%$ \\
\hline \multirow{4}{*}{5.} & \multirow{4}{*}{$\begin{array}{c}\text { Source of family income } \\
\text { of the Respondents }\end{array}$} & Government employee & 31 & $62 \%$ \\
\hline & & Private employee & 00 & $00 \%$ \\
\hline & & Business & 11 & $22 \%$ \\
\hline & & Agriculture & 08 & $16 \%$ \\
\hline \multirow{7}{*}{6.} & \multirow{7}{*}{$\begin{array}{l}\text { Educational level of the } \\
\text { Respondents }\end{array}$} & Illiterate & 14 & $28 \%$ \\
\hline & & Primary & 09 & $18 \%$ \\
\hline & & High school & 03 & $06 \%$ \\
\hline & & Higher secondary & 09 & $18 \%$ \\
\hline & & Degree & 11 & $22 \%$ \\
\hline & & Above degree & 03 & $06 \%$ \\
\hline & & Technical qualification & 01 & $02 \%$ \\
\hline \multirow[b]{2}{*}{7} & \multirow{2}{*}{$\begin{array}{c}\text { Educational Institutions } \\
\text { preferred by the } \\
\text { Respondent's family }\end{array}$} & Government Institution & 20 & $40 \%$ \\
\hline & & Private Institution & 30 & $60 \%$ \\
\hline
\end{tabular}

Source: Primary Data

Age Group of the respondent: Above table shows that most of the respondents (30\%) are from 51-60 years age groups. Beside this $24 \%$ of the respondent belong to $41-50$ age group, $22 \%$ are $20-30$ years age groups, $16 \%$ are $61-70$ years age group, $6 \%$ are from $31-40$ age group, and only a little segment that is $2 \%$ of the respondent are from 71-80 years age group.

Religion: In terms of religion data indicate that majority $64 \%$ of the respondents are Donyipoloism (indigenous religion) i.e. they believe the sun is god. The rest $36 \%$ of the respondents are converted to Christian.

Types of Family: The above data show that majority $72 \%$ of the respondents follow nuclear family structure. Besides that only $28 \%$ follow joint family system. It indicates that the most of the Galo people in Basar circle are gradually shifting from their traditional joint family system to modern nuclear family structure.

Monthly family income of the respondent: The data indicate that $30 \%$ of the respondent has a relatively low monthly income. $24 \%$ of the respondents are rich and beside these only $06 \%$ of the respondents have monthly income below Rs.10, 000 . So we can say that most of the respondents are middle class people.
Educational level of the respondents: Education is the most potent mechanism for the advancement of human beings. It enlarges, enriches, and improves the individual's image of the future. Data show that $28 \%$ of the respondents are illiterate. Whereas $22 \%$ of the respondents are graduate, $18 \%$ higher secondary, $18 \%$ primary, $6 \%$ high school, $6 \%$ above degree and only $2 \%$ have technical qualification.

Educational Institutions preferred by the family: The data show that $40 \%$ of the respondents prefer government educational institutions for their children. Besides that $60 \%$ prefer private institutions. It indicates that besides government institutions, private institutions and NGOs are also playing a significant role in the upliftment of the Galo people in Basar circle.

\section{CONCLUSION}

Education is the key to tribal development. Tribal children have very low levels of participation. Though the development of the tribes is taking place in India, but the pace of development has been rather slow. It can say that the educational status of the respondent of Basar Circle is relatively poor. In spite of a few educational institution especially higher education as compared to valley area most villagers are literate by incorporating all those who can just 
read and write using Roman script except for a few aged people. But the educational life of the younger generations is improving at an alarming rate. It indicates that most of the respondents are now a days in favor of their child's education and they are aware of the benefits of education. The proposed study consists of several villages under Basar circle, of west siang district of Arunachal Pradesh, namely Basar, Bam, Nyigam, Nyodu, Soi and Gori. The main focus of the study is to know about the educational as wellas living condition of the Galotribe in Basar circle.Major Findings of the Study are:

1. As per 2001 India census, total population of Galo tribe in Basar is 3834. They live in over 65 hill villages, traditionally each keeping to itself under a selected chief styled GaonBura (British-era development) who moderates the village council, which basically acts as traditional court and the olden days councils consist of all the village elders and decisions were taken in a large village hall called as Dere.

2. Majority of the Galo people believe in Donyi polo religion. The important festival Galos of Basar circle is Mopin. The people of Basar Circle speaks Galo (Lare) language, which basically is related to Chinese or mongoloid languages.

3. Galo people follow patriarchal system. Now-a-days most of the Galo people in Basar circle are gradually shifting from traditional joint family system to modern nuclear family structure.

4. In terms of income most of the Galo people in Basar circle are earning Rs.10, 000 to Rs.20, 000 per month. And majority of respondent i.e. $62 \%$ in study area are engaged in government jobs. Whereas others are depend on business and agriculture/traditional occupation.

5. The key resource for technical education in Basar is the Tomi Polytechnic College under Rajiv Gandhi University (R.G.U.). NGOs running institution like V.K.V Basar also plays a key role in upgrading the primary educational level as well as character building of the Galo students. So it can be said that both government and private institutions play their role in the upliftment of educational level of the Galo people in Basar circle.

6. Majority of the respondents in Basar Circle are literate and they prefer private educational institutions. New generations are gradually becoming more aware of the governmental schemes and benefits of education and they are in favor of their children's education.

\section{References}

Talesara, Hemlata. (1989). Tribal education. Himanshu publication, New Delhi.

B.Biwas, Nikunja.(2008). Education in Northeast India. Shipra publications, New Delhi.

Singhi, Narendra k. (1979). Education and Social Change. Rawat Publications, New Delhi.

Fraser, A.G, Allan, M.M, Maclean, J.H, Paul, K.T. (1986). Village Education in India. Mithal publications, New Delhi.

Mibang, Tamo and Behera, M. C. (2004). Tribal villages in Arunachal Pradesh: changing human interface. Abhijeet Publication. New Delhi.

Seetharamu, A. S. (1980). Tribes of Arunachal Pradesh. Ashish Publication. New Delhi.

F.M, Schnitger. (1938). Forgotton Kingdoms in Sumatra.E.vanBriel, South Sumatra.

Nair, P.T. (1985). Tribes of Arunachal Pradesh. University Publication, New Delhi

Srivastava, L.R.N. (1962). The Gallongs. Adviserssecetariate, Shilong.

S.T. Das. (1987). Life Style Indian Tribes (Volume-1). Gain Publishing House, Delhi.

M.K. Rahaand P.C. Commar. (1989). Ed. Tribal India Problem Development Project (volume-2).Gian Publishing House, New Delhi.

Devendra Thakur and D.N. Thakur. (1996). Tribal Life and Forests. Deep and Deep Publications, New Delhi.

K.K.Misra. (1994). Tribal Elites and Social Transformation. Inter-India Publications, New Delhi.

Sharma, Usha and S.K. Sharma. (2005). Discovery of North-East India. New Mittal Publications, Delhi.

Patel, S. (1991). Tribal Education in India. Mittal Publications, New Delhi.

Horam, M. (1990). North- East India: A profile. Cosmo Publication, New Delhi.

Grewal, D.S. (1997). Tribes of Arunachal Pradesh: Identity, Culture and Languages (volume- 1). South Asia Publications, Delhi.

\section{How to cite this article:}

Nabarun Purkyastha and Karken Bam (2017) ' Education and livelihood: a sociological study on galo tribe In basar circle of arunachal pradesh', International Journal of Current Advanced Research, 06(03), pp. 2831-2835.

DOI: http://dx.doi.org/10.24327/ijcar.2017.2835.0119 